\title{
Transforming Captivity Narratives in Kevin Willmott's The Only Good Indian (2009)
}

\author{
Laura L. Mielke
}

The Indian captivity narrative genre, or "accounts of non-Indians held by Indians," has long been described as establishing both a triumphalist narrative of national progress and a template for American identity, in contrast with American Indian identity. ${ }^{1}$ As often noted, the Indian captivity narrative is marked by its perpetual metamorphosis, as well as its status "as the archetype of American culture, or its foundation text." Richard Slotkin, in his trilogy on the myth of the American frontier, traces the critical function of the captivity narrative, alongside the story of the Indian fighter, in the development of the colonial project and then national ideology beginning in the seventeenth century. The two figures of the frontier myth that Slotkin identifies - the captive and the Indian fighter - were "codified and systematized" in James Fenimore Cooper's nineteenth-century frontier romances and have persisted in various permutations through popular literature, theater, art, and film to the present day. ${ }^{3}$ While political exigencies informed those permutations, so did cultural confrontation. Focusing in particular on the key roles of gender and familial relations in the genre, June Namias concludes, "The popularity of the captive story came from a fascination with both the other and the self. One's own culture, one's own family, one's own gender, that whole complex of Anglo-American culture one inherited by being raised on the American continent, was brought into relief." 4 The captivity narrative prompted such reflection, argues Joshua David Bellin, and exhibited in a multiplicity of ways the intercultural exchanges that pro- 


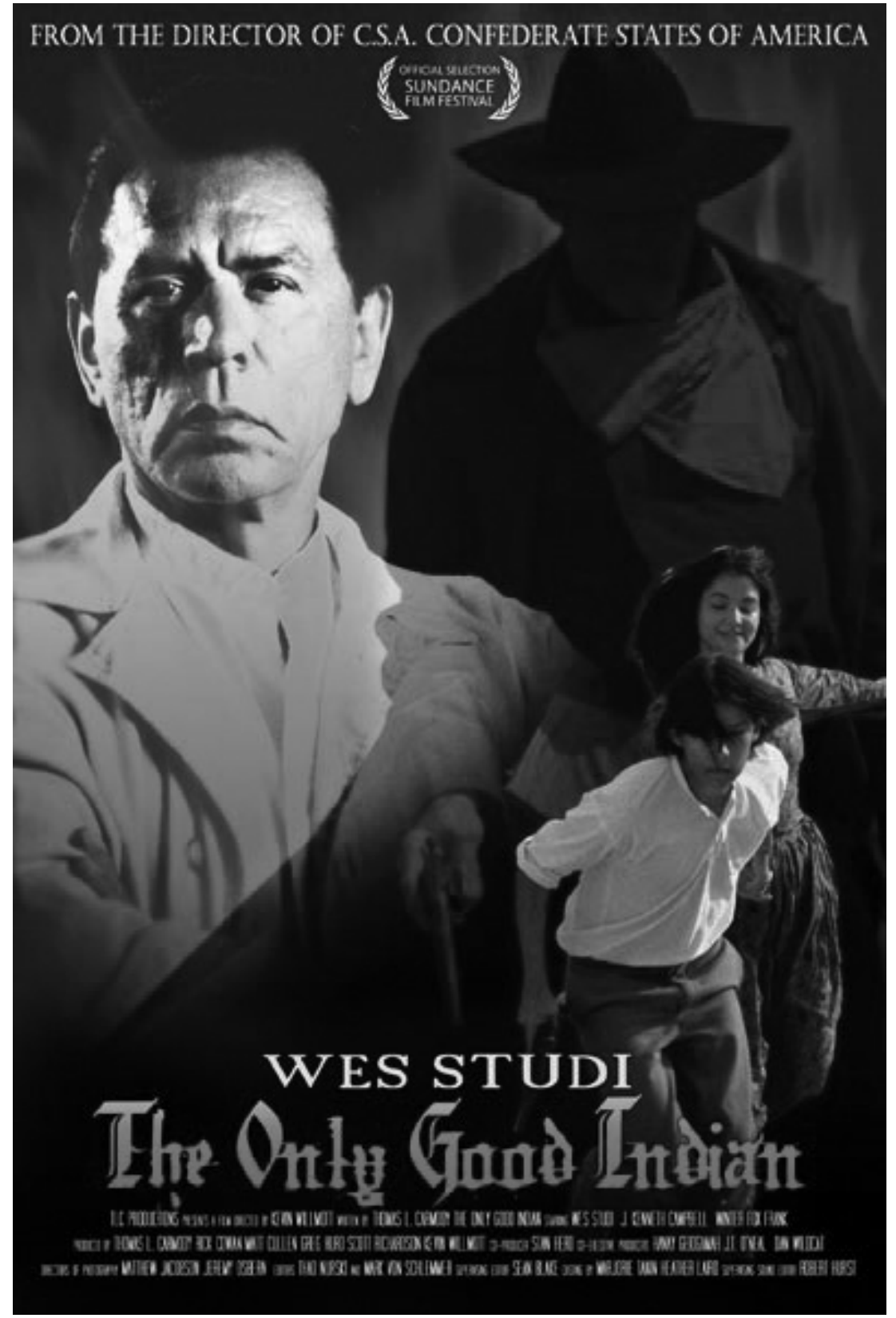

Poster (frontispiece): Poster for The Only Good Indian, directed by Kevin Willmott. Screenplay by Thomas L. Carmody, cinematography by Matt Jacobson and Jeremy Osbern, and still photography by Tyler Carmody. 
duced the narrative in the first place. ${ }^{5}$ Its descendants in literature and in film, for all of their revisions to the historical antecedents, nonetheless carry forward the record of exchange between American Indians and white captives and combatants.

Running parallel yet counter to the Indian captivity narrative tradition are accounts of American Indians held captive, or what have been termed "reverse captivity narratives." ${ }^{\prime \prime}$ In the context of colonial negotiations, warfare, Christian evangelism, and educational institutions, American Indians were repeatedly interned by Euro-Americans determined to exert political-geographical control and to expunge Native culture, particularly through forced English literacy. The resulting as-told-to and autobiographical narratives in English stand as echoes, revisions, and even inversions of the Indian captivity narrative. Alumni of the federal boarding school system, such as Francis La Fleshe (Omaha), Zitkala-Ša (Dakota), Charles Eastman (Santee Sioux), and Luther Standing Bear (Lakota), recount with deep emotion and sharp irony the physical and psychological pain they suffered in the process of acculturation. They also celebrate Native students' "strategies to assert independence, express individuality, develop leadership, use Native languages, and undermine federal goals of homogenization and assimilation." "7 Thus, the reverse captivity narrative, like its foil, takes up questions of individual survival, cultural identity, and national membership.

What happens when the reverse captivity narrative, like the Indian captivity narrative before it, makes its way into other genres, especially film? Does the filmic adaptation of the boarding school narrative echo or depart from the adaptation of the captivity narrative? More specifically, how does the reverse captivity narrative brought to film animate the genre's central concern with linguistic colonialism? And how does the Western - a genre grounded in archetypal struggle between savagery and civilization but perpetually revised since the mid-twentieth century to reflect the violence of US settler colonialism and imperialism ${ }^{8}$ - continue to evolve in the context of American Indians' experience in captivity? In this essay, I begin to answer these questions by focusing on a recent independent film that productively, provocatively embraces the intertextuality of both the Indian captivity and the reverse captivity narratives and their role in the construction - and deconstruction - of a mythic West.

The Only Good Indian (2009), directed by Kevin Willmott, with screenplay by Thomas Carmody, premiered at the Sundance Film Festival in 2009 and was awarded honors at the American Indian Film Festival that same year. ${ }^{9}$ It follows the experience of a young Kickapoo boy forcibly taken from his parents and enrolled in Haskell Institute, a federal boarding school in Lawrence, Kansas, in the first decade of the twentieth century. ${ }^{10}$ Once captive, Nachwihiata (Winter Fox Frank) finds himself shackled by English language as he is rechristened Charlie, forbidden to speak his native tongue, declared a Methodist, and forced to memorize the colonizing language under the strict rule of callous white staff. Nachwihiata subsequently runs away, taking with him the school's copy of Bram Stoker's Dracula (1897), a narrative of vampiric captivity, but he 
is soon captured by Cherokee bounty hunter Sam Franklin (Wes Studi). Franklin is a US Indian Scout and aspiring Pinkerton agent who has abandoned the name of Black Fox and, in his words, aims to "out white man the goddam white man." The winding road back to Haskell proves difficult as Nachwihiata and Franklin kill three white deputies who attempt to take Nachwihiata for themselves, and then Franklin decides to capture for reward another Native fugitive, Sally Lonewalk (Thirza Defoe), who is wanted for the murder of an attendant at the mental asylum where she had been confined and repeatedly raped. Sheriff Henry McCoy (Kenneth Campbell), an Indian-hater who took part in the Sand Creek Massacre of 1864 and subsequently became the subject of popular dime novels and a film, pursues the three with deadly intentions. The film culminates in Franklin's renunciation of bounty hunting and his showdown with McCoy.

As I hope this brief synopsis makes clear, The Only Good Indian recalls the military and institutional atrocities committed against American Indians from the Civil War through the early twentieth century by explicitly juxtaposing Indian boarding school experiences with conventions of the Western and the horror film, genres that The Only Good Indian ties to earlier literary traditions, namely, the captivity narrative, the dime novel, and the gothic novel. Furthermore, as Willmott has discussed in interviews, the film draws inspiration from the blaxploitation films he watched as a youth. ${ }^{11}$ Like Gordon Parks, Willmott is a Kansan, and his position as a midwestern, African American filmmaker and academic clearly informs his work's profound engagement with the history of US race relations and playful use of film genres and history. ${ }^{12}$ The "meta-text feel"13 of The Only Good Indian is at once representative of Willmott's artistic project and deeply suited to the subject matter.

With an analytic focus on the interplay of film and literary genres, augmented by attention to specific historical referents in Kansas and to statements by the director and screenwriter, I show in what follows how The Only Good Indian not only makes horribly immediate the physical and cultural violence suffered by nineteenth-century American Indians but also makes manifest the mutation of non-Native cultural forms, especially the captivity narrative tradition, in the hands of resourceful, resistant, English-fluent American Indians. The Only Good Indian unites a critique of the boarding school's linguistic colonialism with a self-reflexive meditation on how narratives arising from the context of captivity are transformed by the captive from the tool that binds to the weapon that liberates.

\section{Resistance and the Boarding School Narrative}

In September 1884, the first students arrived at the US Indian Industrial Training School in Lawrence KS, known by most as Haskell Institute, one of twenty-five federally funded Indian boarding schools founded between 1879, when General Richard Pratt opened the first off-reservation Indian boarding school in Carlisle, Pennsylvania, and 1902. ${ }^{14}$ Pratt firmly believed that without 
acculturation, American Indians were destined to declension and disappearance, and he infamously asserted that Haskell and other institutions would "kill the Indian and save the man." ${ }^{15}$ In The Only Good Indian, these words appear on a poster in the superintendent's office, glossing scenes of the students' introduction to the harsh work and educational environment of the school. The Haskell of the film stands in for the boarding school system writ large, and the school scenes capture strategies employed in schools from Carlisle, to Salem, Oregon, to Genoa, Nebraska, to achieve "total transformation, obedience, and assimilation into colonial culture." ${ }^{16}$ Western hygiene and dress, military regimentation, Christian worship, industrial training, and English-only rules were strictly enforced. The Only Good Indian captures the widely documented trauma of students subjected to compulsory haircuts and dental work, backbreaking manual labor, relentlessly scheduled days, degrading corporal punishment and solitary confinement, insufficient food and medical care, and the stripping away of Native dress and language, making palpable the resemblance of matriculation to captivity.

The Only Good Indian emphasizes in particular the imposition of English on students, the way in which Haskell staff "intended to weaken tribal bonds and suppress 'profane' (i.e., Indian) language and conduct." 17 The film opens with Nachwihiata and his parents sneaking out to an open field so that father and son may play lacrosse. The pastoral scene is interrupted by the arrival of three men on horseback - two white men and a Kickapoo police officer; the latter restrains the mother, while the others beat Nachwihiata's father and lasso and hogtie the boy for delivery to the local train station and transport to Haskell. Few words are spoken in the opening scenes of the film, but we do hear the protests of Nachwihiata's mother in Kickapoo and his father's pointed appeal in English: "No, please. He's a good boy. He's learning your language!" The information does not deter the men, though it signals the father's understanding of the school's priorities.

The film introduces the viewer to the linguistic colonialism of the boarding school classroom through the words of the superintendent to his charges"Never should we hear your tribal language spoken in the halls of this institution"- and through an act of resistance by Nachwihiata, renamed Charlie. The teacher, Miss Harris (Laura Kirk), asks her students how long they have been at Haskell. When no one responds, she calls on Nachwihiata: "Charlie..., you got here in April, it is now September, so you've been here how long?" He responds in Kickapoo, "nekotwaasika" (six). Stiffening, Harris rises and proclaims, as a bell tolls in the background, "That, children, is being a bad Indian. The correct answer is six." When Nachwihiata persists with answering in Kickapoo, she coolly directs him, "Go see Mr. Joseph. Immediately." As the boy leaves, Harris discovers the school copy of Dracula hidden under the boy's slate, proof of his considerable literacy in English. Still, an unwillingness to abandon Kickapoo and speak English in the classroom makes Nachwihiata a bad Indian. He is subsequently beaten, has his mouth forcibly washed with soap, and is confined 
to a dark cell-documented practices at Haskell and other institutions. Harris visits the confined Nachwihiata, as the child in the adjacent cell cries out to be released, and brings him Dracula in a weak attempt to connect with the resistant child. As she leaves, Nachwihiata crosses his fingers to ward off evil, having discerned that the school expects its captives to relinquish their language or their lives. In a school governed by Pratt's words, another infamous phrase from the nineteenth century that provides the title of the film, holds true: "The only good Indian is a dead Indian."18 The boarding school system's desire to eradicate Native language and culture is, finally, part of the genocidal impulse that governed US military actions from the Ohio Valley to Wounded Knee. To be a "bad Indian" is to be alive. ${ }^{19}$

According to Carmody and Willmott, the early scenes of The Only Good Indian draw not only from various histories of US Indian boarding schools in this era but also from many conversations with American Indian consultants to the film, especially playwright Hanay Geiogahma (Kiowa/Delaware), Haskell Indian Nations University American Indian Studies professor Dan Wildcat (Muscogee), and boarding school survivor George Whitewater (Kickapoo), who provided language consultation and the name Nachwihiata. ${ }^{20}$ The film team worked closely with the Kickapoo Tribe of Kansas and the Prairie Band Potawatomie Nation, on whose lands they filmed multiple scenes. ${ }^{21}$ Careful attention to Native histories and languages results in a film that resonates deeply with the written record of the boarding school experience, amplifying the film's intertexuality and its summoning of neglected narratives.

The Only Good Indian echoes many of Haskell student writings from this period and, like those writings, makes vivid the ways in which a language curriculum designed to eradicate Native culture ironically promoted alliances among Native students and prompted narratives preserving students' actions of resistance. Writings by boarding school students and alumni stand as examples of what Gerald Vizenor famously calls the literature of survivance, through which authors like Standing Bear "counter the surveillance and literature of dominance with their own simulations of survivance," the necessary union of resistance and survival. ${ }^{22}$ Native public intellectuals such as Standing Bearmany of them boarding school alumni-acquired and refitted narrative and performative tools subsequently crucial to cultural and political, individual and collective, acts of Native resistance in the progressive era. ${ }^{23}$

Without what Theresa Milk deems "stories of sacrifice and survival," twenty-first-century readers would not have a rich account (one that prompts further accounts, like the film) of the complex ways in which Haskell students resisted the boarding school experience, including the forced use of English. ${ }^{24}$ Letters home document progress in English but also complaints about work, medical care, food, and strict social rules - hardships vividly depicted in The Only Good Indian. Other writings by students illustrate how English skills translated into direct resistance to the process of acculturation. For example, students wrote to protest mistreatment; in 1888, nineteen male students ages sixteen to twenty- 
seven reacted to the rampant illness at the fledgling school through a petition stating their urgent desire "to know what is the cause of so many deaths among us," ${ }^{25}$ and in 1917, the "Girls of Haskell" wrote the Commissioner of Indian Affairs requesting the removal of matron Katherine Keck. ${ }^{26}$ Testimony by Haskell alumni in autobiographical writings and recorded interviews indicate the ways in which English fostered intertribal bonds. ${ }^{27}$ Former Haskell student Esther Burnett recalls in her memoir,

We had a lot of respect for each other's culture and talked about our customs and traditions. We students nurtured a sense of community among ourselves, and we learned so much from each other. Traditional values, such as sharing and cooperation, helped us to survive culturally at Haskell, even though the schools were designed to erase our Indian culture, values, and identities. ${ }^{28}$

Myriam Vučković summarizes, "Again and again, indigenous people used federal Indian education to further their own needs, including the preservation of identity, and proved more receptive to learning and more creative in culturally appropriating their education than white policymakers ever imagined." ${ }^{29}$ In The Only Good Indian, Nachwihiata resists the English-only policy while finding refuge - and as I discuss later, strategy — in the pages of a well-known gothic captivity narrative.

Like La Flesche's The Middle Five: Indian Schoolboys of the Omaha Tribe (1900) and Zitkala-Ša's three autobiographical short stories that first appeared in The Atlantic Monthly (1900-1), The Only Good Indian dramatizes how boarding school students used English to retain and celebrate Native culture. The connections between these works and the film apparently stem from the commonalities across boarding schools, because Willmott and Carmody consulted neither work specifically. Still, meaningful similarities exist, illustrating the uses to which boarding school students put English in their efforts to retain and celebrate Native culture. La Flesche, who was born on the Omaha reservation in Thurston County, Nebraska, in 1857, attended during the mid-1860s a boarding school established on the reservation by the Presbyterian Board of Foreign Missions for the Omaha people. ${ }^{30}$ Zitkala-Ša (Gertrude Simmons Bonnin) was born in 1876 on the Yankton Reservation in South Dakota and attended White's Manual Labor Institute, in Washbash, Indiana, from 1884 to 1887 and again in the 1890s, briefly attending Santee Technical School in Nebraska in the interim and subsequently enrolling at Earlham College in $1895 .{ }^{31}$ In their respective accounts of the boarding school experience, La Flesche and Zitkala-Ša invert the Indian captivity narrative and its governing binary of savage versus civilized. These former boarding school internees blend the tropes of memoir and fiction, spinning youthful memories into powerful testimony to the cruelty of a system bent on acculturating Indian children. 
Such narratives resonate with the depiction of Nachwihiata's experience at Haskell. In "The School Days of an Indian Girl," Zitkala-Ša recalls the shock of entry to the boarding school environment, where she is callously manhandled. When she attempts to avoid a haircut by hiding under a bed, she is dragged out and tied to a chair. "Not a soul reasoned quietly with me, as my own mother used to do," she bitterly recalls, "for now I was only one of many little animals driven by a herder." 32 In The Only Good Indian, a montage of Nachwihiata's initiation into the school system includes his being tied to a chair for a haircut, strapped to a chair for dental work, and pushed into a chair for photographing. Over such scenes, the superintendent's introductory remarks to new students may be heard: "This is not a prison. There are no walls or fences. But there is a clock. The clock is here to provide order and discipline." Zitkala-Ša's account likewise portrays the boarding school's "iron routine" of work and study, along with the "cruel neglect" of the students' bodily and mental health. ${ }^{33}$ Zitkala-Ša recounts the death of a beloved friend belatedly treated for illness, and The Only Good Indian depicts Nachwihiata digging a grave for a classmate-one child's grave among many in the Haskell cemetery.

Interspersed with the school staff's heartless acts in both of these boarding school portraits are the students' attempts to bring the institution to a halt. In response to "unjustifiable frights and punishments," the young Zitkala-Ša becomes subversively destructive, from overzealously mashing turnips until the container breaks to defacing a picture of the devil in a book of Bible stories, "testing the chains which tightly bound my individuality like a mummy for burial." 34 Nachwihiata's resistance does not end with his haircut or defiance of Harris. A young friend who clandestinely speaks with Nachwihiata in Kickapoo declares, "I have had my fill of whistles, bells, and clocks," and that night the boys destroy the clock in the school's tower by inserting a buffalo nickel in its gears [Figure 1]. Captured and beaten, Nachwihiata is next shown digging the grave mentioned earlier, after which he declares his intention to run away. Less than sixteen minutes into the film, Nachwihiata flees Haskell, never to return; however, like the few pages in which Zitkala-Ša recalls her early days at school, the images haunt the remainder of the narrative. ${ }^{35}$ As Haskell Indian Nations University professor Julia Good Fox (Pawnee) writes, "the institute remains an ever looming presence, or specter, throughout the film." 36

The bond between Nachwihiata and his school friend and the relationships Nachwihiata forms subsequently with Sally and Franklin echo accounts of the formation of ad hoc families within the boarding school context. One finds this particularly in La Flesche's The Middle Five, which celebrates the bonds among five boys enrolled in the boarding school for the Omaha tribe. Frank, Brush, Lester, Warren, and Edwin (Oo-má-a-be) comfort one another, fight for one another, share oral traditions, divide treats, sneak away from school together, and collectively resist the authority of their teacher, Gray-beard. Time and again, they exemplify the resourcefulness of American Indian children as they retain and even build cultural and familial ties in the context of captivity, 


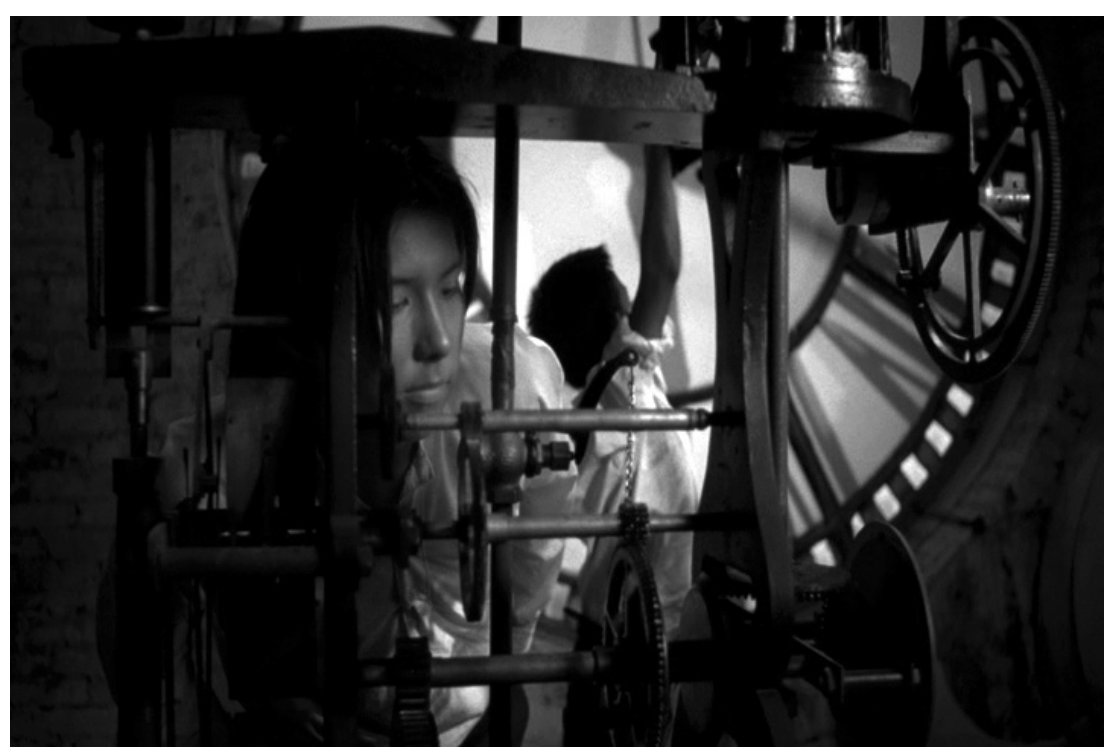

Figure 1: Nachwihiata (Winter Fox Frank) and fellow Haskell student damage the school clock.

an aspect that informs The Only Good Indian's portrait not only of Nachwihiata's new relationships but also, I would argue, of his strategic appropriation of an English-language novel amid captivity. The hero of The Middle Five is the orphan Brush, a diligent student who serves as the leader of the group; the work opens with Brush comforting the young Frank on his arrival at the school and concludes with Brush's death from tuberculosis. Brush always has a book in his hand-we discover him reading in the grass, under a tree, and even on horseback ${ }^{37}$ - and shares what he reads with the other boys. His commitment to his education and to his friends lends him moral authority with the white leaders of the school, as well as with his classmates. When Gray-beard beats a younger student's hand with a board for accidentally hitting the teacher with a dirt clod, an act that "created in [Frank's] heart a hatred that was hard to conquer," 38 Brush intervenes by narrating the injustice to the superintendent, which leads to Gray-beard's apology. Through Brush, The Middle Five offers an alternative model for the correction of boarding school abuses; however, its celebration of Brush as a model of assimilation, as well as the sentimental treatment of his death, disappoints many modern readers. ${ }^{39}$ Yet taken together, Brush's forceful claim to Christian principles and the other boys' outward acts of defiance provide a complex account of the many ways in which boarding school students resisted and changed from within the civilizing program.

Boarding school narratives, be they oral histories, letters, petitions, or literary texts, remind us that students of these institutions were captive to an often-heartless system that rarely paused to ask, as Zitkala-Ša did, "whether 
real life or long-lasting death lies beneath this semblance of civilization." They also make palpable the ways in which students often claimed agency through the language forcibly imposed upon them. ${ }^{40}$ "Covert resistance," writes Lomawaima, "has been a hallmark of colonial education." 41 Profoundly reverberating with key boarding school narratives, The Only Good Indian makes such resistance, as well as the horrifying institutions that spurred it, visible in the twenty-first century.

\section{Dracula and Captivity}

In Gunfighter Nation, Slotkin observes that "although horror/slasher movies have their own generic history, they are very much in the captivity rescue traditions." ${ }^{2}$ The drama of the traditional Indian captivity narrative, like that of the horror film, resides in the white protagonist's traumatic dislocation and injury, witnessing of spectacular brutality, and miraculous survival. In the years just prior to The Only Good Indian, two independent films appeared that draw upon such horror conventions to reverse the traditional narrative of white suffering at the hands of Indians and capture American Indians' persistent experience of colonialism. Imprint (2007), directed by Michael Linn and produced by Chris Eyre (Cheyenne and Arapaho), takes on a prejudiced US judiciary through the story of a successful lawyer's return to her family's home on the Pine Ridge Reservation and her discovery through visions of her brother's murderer. Older than America (2008), directed by Georgina Lightning (Samson Cree), focuses on the fatal abuse and neglect of Native children placed in a Catholic boarding school and the ways in which the boarding school experience literally haunts the Fond du Lac reservation. ${ }^{43}$ Both films move beyond the stultifying sympathy of late twentieth-century film Indians (think Dances with Wolves, 1990) through the foregrounding of Native perspective and attention to contemporary injustices. ${ }^{44}$ In addition, the films are connected as much by their attention to Native spirituality - respect for elders, attentiveness to visions, the sacredness of communal ritual, a cyclical understanding of time - as by their adaptation of the horror genre and the captivity narrative before it. Willmott and Carmody take up this indigenous use of horror and, in the context of a historical drama, reach back to the literary precedents of the genre, namely, British gothicism, to rework a central trope of the Indian captivity narrative: the white captive's ameliorative reflection on scripture.

Just after The Only Good Indian offers a montage of Nachwihiata's initiation to Haskell, we find him amid students reciting the English alphabet under the charge of Harris. He does not chime in; instead, his eyes, and ours, wander over the titles of novels on the classroom shelf: Ann Radcliffe's The Mysteries of Udolpho (1794), H. G. Wells's The Invisible Man (1897), Horace Walpole's The Castle of Otranto (1764), Robert Louis Stevenson's Strange Case of Dr. Jekyll and Mr. Hyde (1886), Mary Shelley's Frankenstein (1818), and Stoker's Dracula. These works represent the heart of British gothicism, a literary genre 
marked by "haunted houses, evil villains, ghosts, gloomy landscapes, madness, terror, suspense, horror, ${ }^{45}$ and I would add, physical confinement (in a prison, in a secret chamber, in a tomb). As if sensing the relevance to his new situation, Nachwihiata is drawn to the copy of Dracula, whose exposed spine bears its title in lurid red. Stoker's classic vampire tale begins as a narrative of captivity and murder and becomes an account of successful, bloody revenge. In the process of finalizing a real-estate purchase in London, Count Dracula holds Jonathan Harker, an English solicitor, captive in his Transylvanian castle and after arrival in England victimizes Lucy Westenra and subsequently her friend Mina Murray, Harker's fiancé. A group of men, including Lucy's fiancé and the vampire hunter Van Helsing, must behead Lucy and drive a stake through her heart after she rises from the grave a vampire. They eventually save Mina from such a fate by slaying Dracula, the one American of the group piercing the count's heart with a bowie knife. For Nachwihiata, this violent fiction of blood and land lust serves as his field guide to Haskell and territories he must traverse to return home. ${ }^{46}$

Dracula provides all of the words for Nachwihiata's narration of the film, which begins immediately following the title sequence. As Nachwihiata and other captive children travel to Haskell by train, we hear, "Chapter 1. 'For the dead travel fast" ${ }^{\prime \prime} 47$ and briefly see the image of the novel's first page transposed over a boy's bound hands. After he has selected Dracula from the classroom shelf, Nachwihiata walks across the campus, over which we hear his voice offer this relevant excerpt from Harker's diary: "Chapter 2. It all seemed like a horrible nightmare to me, and I expected that I should suddenly awake, and find myself at home. ... There is but one thing to hope for: that I may not go mad, if, indeed, I be not mad already." ${ }^{\prime 4}$ From these first two uses of the novel as narration, and the recurring images of actual pages from the novel and Nachwihiata reading [Figure 2], the audience realizes he is captive to a force determined to extract the land, labor, and culture of Indians, with no regard for their lives. Stoker's words powerfully gloss such images as the Haskell graveyard, zombie-like asylum inmates, greedy posses seeking rewards for turning in children, and a bloodthirsty sheriff in unceasing pursuit.

The accounts of European captivity among American Indians in North America date back to the narrative of Alvar Núñez Cabeza de Vaca in the midsixteenth century, but many consider Mary Rowlandson's The Sovereignty and Goodness of God (1682), an account of her captivity among Nipmuc, Narragansett, and Wampanoag Indians during King Philip's War (1675-6), to be the narrative that establishes key tropes and themes of the genre and governs subsequent reader expectations. ${ }^{49}$ Notably, Rowlandson moves through the trials of her captivity with a book in hand: a looted Bible bestowed by her captors, which she declares serves as "my Guid by day, and my Pillow by night." As the narrative makes clear, Rowlandson followed the New England Puritan practice of reading the Bible typologically, or assuming scripture foreshadowed - provided the types for-all human history. Sacvan Bercovitch explains 


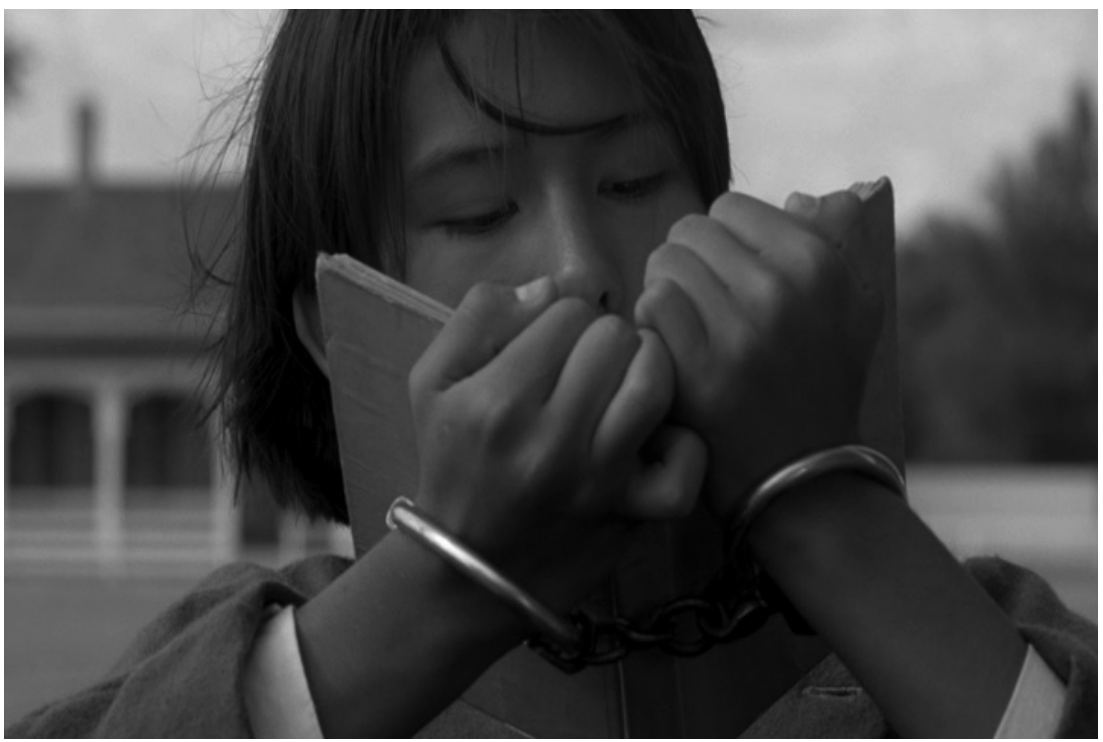

Figure 2: Nachwihiata reads Dracula in captivity in The Only Good Indian.

that "typology merged the saint's life with scripture history" 51 such that the story of the Israelites served as a model for the New England Puritan's colonial project, a New Canaan, and the trials of Job in particular indicated to Rowlandson that the supreme God of her title designed her captivity as a sanctifying or purifying experience for herself and for the colony. Rowlandson's vision of Providence necessarily excluded American Indians from salvation, as she typologically interpreted her captors, including the Christianized "Praying Indians" of the region, to be little more than "the hungry Lyons when Daniel was cast into the Den." 52 The narrative's dismissal of all American Indians as heathens excluded from the work of salvation points toward the perpetuation of genocidal wars well after the brutal torture and beheading of King Philip. As Bercovitch explains, Rowlandson's popular text and the subsequent captivity narratives it inspired transformed "evidence of private regeneration into a testimonial for the colonial cause" and ultimately "a guide to the American future." 53 The typological readings of the Bible endorsed by Rowlandson's narrative point toward the racialist logic of the Western genre, in which whites battle Indians for the soul of the continent.

What, then, does it mean for The Only Good Indian to replace Rowlandson's Bible with Nachwihiata's Dracula - to swap gothic narrative for scripture in the context of captivity? Broadly speaking, the gothic mode resists teleological interpretation of the Puritan kind, including interpretation making inevitable the white Christian conquest of Native America, as it deals with the emergence what has been denied and suppressed. Reflecting on gothicism in the American context, Teresa Goddu writes, "The nation's narratives - its foundational fictions and self-mythologizations - are created through a process of displace- 
ment: their coherence depends on exclusion. By resurrecting what these narratives repress, the gothic disrupts the dream world of national myth with the nightmares of history." ${ }^{4}$ Good Fox likewise ponders "a connection between Europe's confrontation with the Western Hemisphere-a cataclysmic event that forced Europe to confront its religious and philosophical foundations - and the rise of such literary English genres as Gothic and Horror." ${ }^{55}$ Dracula offers Nachwihiata a guide to the dominant culture that, unlike the mail-order catalog of white man's goods that Franklin recommends to him, does not hide the culture's corrupt and decaying soul.

Yet the film's reading of Dracula is no less typological than that of scripture in The Sovereignty and Goodness of God. As Rowlandson interprets the Indians to be "instruments of God" rather than independent agents, ${ }^{56}$ so Nachwihiata aligns all who contribute to the operation of the boarding school with the undead who feast on the living and do the count's bidding. Such a description of the federally mandated acculturation process makes sense in light of the boarding school's emphasis on manual labor and disregard for the physical welfare of Native students. Willmott and Carmody register the Dracula parallel visually by bringing a "horror-film feel. . ., a gothic feel" to the scenes in Haskell and the insane asylum. ${ }^{57}$ Blood runs down Nachwihiata's face and back when he is whipped; a captured runaway girl mockingly dressed like a clown stands the dark recess of a school hallway; the superintendent writes a death announcement to a child's parent while espousing the virtues of the school; children communicate through ornate iron bars and the walls of cells. At the insane asylum from which Sally has escaped, the warden feasts on rare steak while surrounded by jars of preserved organs and biological oddities, and the patients shuffle across the lawn like zombies. We learn that as a US Indian Scout, Franklin (then Black Fox) participated in the Sand Creek Massacre of 1864, in which around 150 Southern Cheyenne and Arapahoe Indians were brutally killed and mutilated by the First Colorado Cavalry and short-term enlistees under the command of Colonel John Chivington. ${ }^{58}$ That Franklin now makes a living in part from ransoming runaway Indian children - he calls them "red niggers"- indicates vampiric transformation. No wonder, then, when Franklin makes a pilgrimage to the fort where he was once stationed, he discovers the carcass of a large bat in the former Indian Scout bunker.

Nachwihiata finds in Dracula the type for McCoy, also a veteran of Sand Creek, whose avid slaughter of animals and men alike in the nineteenth century have made him a celebrity in the twentieth. McCoy is the subject of a series of dime Westerns and, as he learns while on the hunt for Franklin and the runaways, a new film that glorifies frontier violence. He is joined by Mean Joe (Christopher Wheatley), a young man who abandoned his job as disciplinarian at Haskell to ride with his hero. But McCoy, who appears to detest the doting thug, reveals to him the inglorious truths of Western heroism through the story of his rivalry with William Cody, a.k.a. Buffalo Bill. To best the buffalo-killing record of Cody, McCoy tells his riding partner one night, he once killed 106 
buffalo in a single day. In anger over his desecration of their sacred hunting grounds, a Native war party attacked McCoy and left him for dead with a knife in his back, and the blade of the knife is still lodged within him. As we learn later, Franklin is the one who discovered him and hauled the body twenty-five miles to town, assuming his foe was dead and wanting to know where he was buried. "Hell, injun," McCoy shouts at Franklin in their first standoff, "you oughta know more than anyone, I ain't never gonna die." Addicted to painkillers and plagued by nightmares, McCoy tells the alternately starstruck and horrified Joe, "I don't feel a goddam thing," and later, "I only ride with the dead." Called "evil one" by the students of Haskell and "devil" by Franklin, McCoy represents the unspeakable violence of the West and the undying myth of a glorious frontier where civilization bested savagery. He pays dearly for the typological readings he affords white America.

Franklin accedes to the typological reading in light of McCoy's miraculous survival of the knife wound: "That's when I knew their god was stronger than ours," he tells Nachwihiata. "And it's just meant for them. It's written in their book. They keep comin' and comin' and comin' and they don't stop until they get what they want." The lesson, he continues, is clear: "That's the white man. That's how you survive in this world. And that school will teach you that. That's why you have to go back there." But Nachwihiata finds in the pages of another one of "their" books that, as he tells Franklin, "You can kill them. The Count, he was killed with a bowie knife to the heart." In Nachwihiata's hands, Dracula serves as a liberating mirror, not only encapsulating the horrors of captivity but also providing a strategy or roadmap for defeating the captor and others in his thrall. If Rowlandson finds in her Bible an account of Providence that gives meaning to her suffering and justifies her understanding of Native Americans as agents of the devil, Nachwihiata finds in Dracula an account of the captor that denies his invincibility. That account is prophetic. In a final showdown in the stone ruins of an old church, which is introduced by a passage concerning the pursuit of Dracula, Franklin beats McCoy on the back with a wooden cross that fatally drives the buried blade through his chest. Visually, the Indian redeploys a tool of colonization, but at the same time, the homicidal, guilt-ridden agent of American colonialism contains his own bloody undoing.

The presence of Dracula in The Only Good Indian as narrative source and interpretive lens encourages a more nuanced understanding of the English-literate Indian than Franklin offers in the opening of the film. Franklin's use of English appears inextricable from his pursuit of the white man's "way of life," as seen in his embrace of Western dress and technology and his attraction to the US army and the Pinkerton Agency rather than the Cherokee tribe. He tells Nachwihiata soon after they depart Haskell, "Listen, boy. Sam Franklin is going to be the best white man he can be. I'm gonna out white man the goddam white man. And I'm gonna take you back to that school so you can be one too." Persistently resistant to the doctrine of assimilation, which is Franklin's "philosophy and theology," ${ }^{19}$ Nachwihiata does not reject English when he may 
use it on his own terms. He employs English narrative (Dracula) as Franklin eventually employs the cross: as a weapon. This brings about the reclamation of Black Fox, who sees his captives returned home.

The resemblance between captive Rowlandson's use of the Bible and captive Nachwihiata's use of Dracula constitutes a rejection of the Indian captivity narrative tradition from within. The uncanny resemblance of the boarding school staff and Indian-hating bounty hunters to the blood-sucking count and his minions inverts a tale of consecrating agony and predestined victory into one of deadening cannibalism. In The Only Good Indian, the binary of savagery versus civilization (cowboy versus Indian) and the national faith in manifest destiny are not underwritten by divine scripture but by the dime novel, Wild West show, and Western - genres that, read alongside Dracula, emerge as selfserving myths of white dominance. Franklin, and by extension the film, drives a stake through the heart of the iconic frontier hero and in the process completes the title's infamous phrase with new words and images: the only good Indian is resistant, resourceful — and vibrantly alive.

\section{The Anti-Searchers}

"The Western movies, of course," writes Vizenor, "are not cultural visions, but the vicious encounters with the antiselves of civilization, the invented savage." ${ }^{60}$ The Only Good Indian, like a number of revisionist Westerns since the 1960s, inverts this civilized-savage binary and deals "reflexively with both American history and the history of the Western film." ${ }^{\prime 61}$ Moreover, as Willmott emphasizes, it attempts to share a Native story from a Native perspective without "a white surrogate in the film to make the story "OK." ${ }^{62}$ The anchoring historical events of the film are not romanticized frontier battles between whites and Indians but the boarding school experience and the Sand Creek Massacre. Here, the true savages do not terrorize goodhearted representatives of white civilization; they run governmental institutions, own shops, work desk jobs, and beat Native children. The film's antihero, Franklin, is an American Indian who rides a motorcycle with a sidecar rather than a horse and dons not buckskin and feathers but a long white duster and leather helmet with goggles [Figure $3] .{ }^{63}$ In addition, the film directly comments on the Western genre through the presentation of McCoy as the subject of and audience for the silent film "The Indian Fighter: The Saga of the Immortal Henry McCoy." McCoy watches with increasing unease the film's depiction of an Indian raid, a burning home, captured white women and children, and pitched battles between cowboys with pistols and Indians in white headdresses; he eventually grows hysterical, standing to shout "No! No! No!" to the celluloid myth before him. When Joe later parts ways with McCoy, he declares he's headed off to California to get into the movies. "If you're gonna go out there and lie, make it a big one," McCoy tells him, gesturing to the theater behind him, "“cause the bigger the lie, the more they believe it." ${ }^{\prime 64}$ 


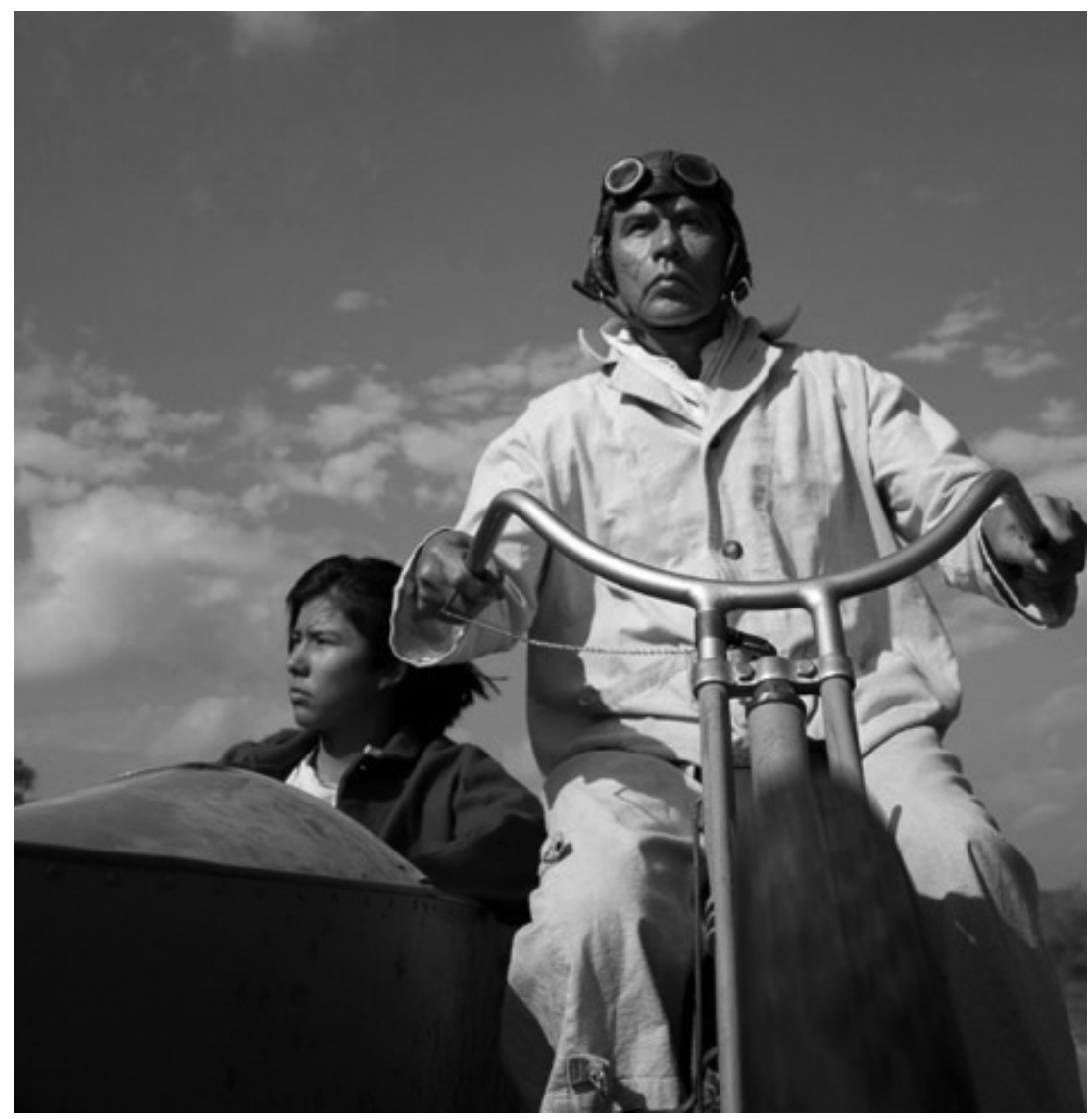

Figure 3: Sam Franklin/Black Fox (Wes Studi) transports the captured Nachwihiata with his motorcycle.

The film engages most directly the iconic Western The Searchers (1956), John Ford's adaptation of a novel by Alan LeMay based on the true story of Cynthia Ann Parker who in 1836 was captured as a child by Comanche Indians in Texas and lived as a Comanche wife and mother until her forcible recapture in $1860 .{ }^{65}$ In the film, Ethan Edwards (John Wayne) doggedly pursues the Comanche who brutally killed his brother's family and captured his niece Debbie (Natalie Woods). A likely outlaw and dyed-in-the-wool racist, Edwards only grudgingly allows Martin Pawley (Jeffrey Hunter), the "half-breed" adopted son of the murdered family, to accompany him and, disgusted by the sexual taint of the female captive, plans to kill Debbie once he finds her. The "ultimate Indian-hater," ${ }^{\prime} 6$ Edwards nonetheless relies on his expertise in Comanche culture and language to find the girl. As Armando José Prats writes, "Whiteness both empowers and justifies [Edwards's] necessary cultural appropriation, the 
mythically mandated descent into savagery. ${ }^{967}$ In the end, Edwards does not kill Debbie but returns her to an adoptive family for reintegration into white life and then walks off into the sunset. The Only Good Indian is "the antiSearchers," because it follows "an Indian getting an Indian back" with ambiguity concerning the location to which the Westernized searcher will restore the captive: home or boarding school. ${ }^{68}$ In addition, the captive first escapes of his own volition and manages to persuade his second captor not to take him back to the white world. Nonetheless, the searchers of this Western - two characters that resemble and disassemble the Edwards figure - are "more alike than different, ${ }^{69}$ doubled across the white-Indian divide.

Franklin may not look like Edwards, but the ethos of self-sufficiency and independence is identical. ${ }^{70}$ Franklin uses the latest technology, including rapidfire guns and hand grenades, as well as the motorcycle, to secure parity with the bounty hunters of the West. For this reason, he has abandoned his Cherokee name and any tribal or pan-tribal affiliation. "I ain't your goddam brother," he tells Nachwihiata in a speech fitting of Edwards; "Now get up, injun." His determination to return Nachwihiata to the boarding school and Sally to the authorities who intend to execute her is no less terrifying than Edwards's plan to kill Debbie, especially because Franklin is certain his actions are correct, as well as lucrative. In addition, Franklin does not hesitate to associate first with the US Army as an Indian Scout and then with the notorious Pinkerton Agency as a private detective or security agent. Edwards likewise moved from service in the Confederate Army to legally ambiguous but profitable activities in the West. But whereas Edwards chooses only in the final gun battle of the film to refrain from killing Debbie, Franklin reaches his turning point before the concluding shootout, as Nachwihiata convinces him to help break Sally out of jail and turn down an offer to become a Pinkerton agent. Franklin then abandons his ailing motorcycle and appropriates a horse and cart; when the surprised owner asks his identity, Franklin - now Black Fox-responds in Cherokee, "I am a member of the Cherokee Nation." From that moment on, the searcher has become the redeemer-Sally's "father," as Charlie tells the Quaker couple that takes her in - and attention turns to the defeat of the remaining pursuer.

Sheriff McCoy resembles Edwards from his hat and scarf to his boots, stiffly striding across the open landscape and swiftly firing at those who stand in his way [Figure 4]. His history with Buffalo Bill and the Indian wars confirm a deep-seated racial hatred like Edwards's. Yet McCoy rejects the boarding school and other modern responses to Anglo-America's perpetual "Indian problem," telling Haskell's superintendent: "I spent all my life clearing devils from this land...but this place? It's crueler than anything I ever done." The pronouncement, and McCoy's subsequent murder of a white man who makes a living capturing Indian children, bolsters the film's critique of the boarding school and fosters partial sympathy for a villain who has "respect for the warrior class" and a severe case of post-traumatic stress disorder. ${ }^{71}$ Yet insofar as McCoy's denouncement of acculturation recalls Edwards's knowledge of Co- 


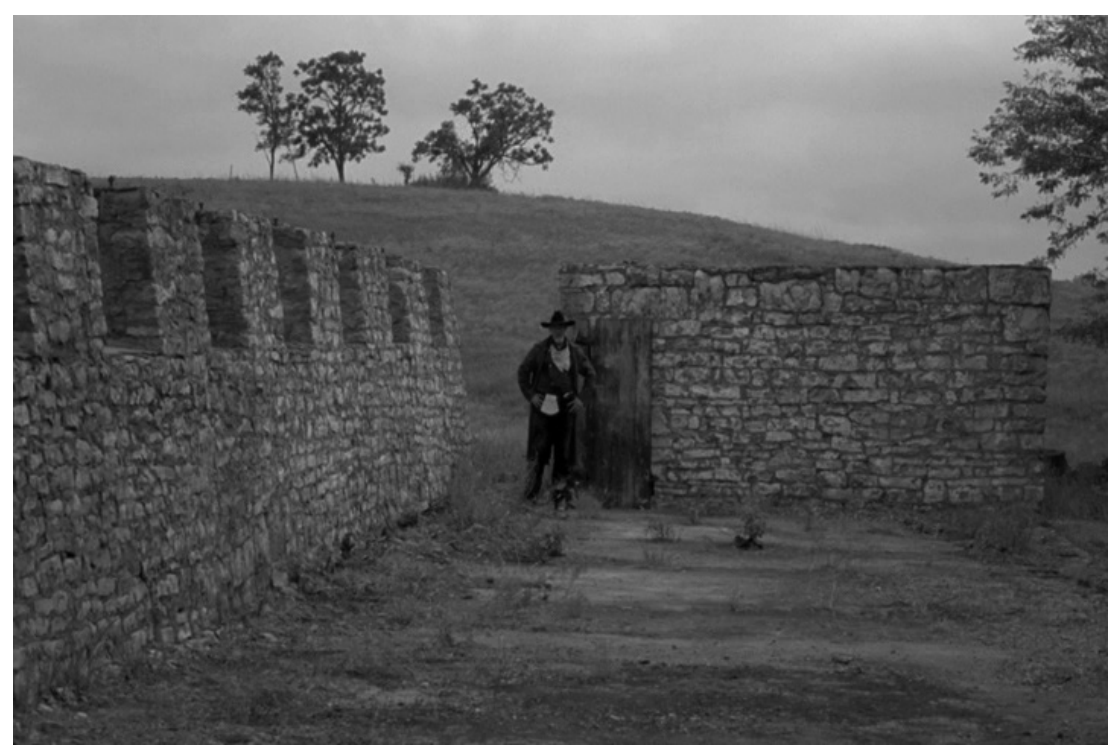

Figure 4: Hank McCoy (Kenneth Campbell) bears a strong resemblance to Ethan Edwards (John Wayne) of The Searchers (1956).

manche culture, one understands McCoy would rather kill than convert a noble foe. The association of McCoy with the central character of one of the most famous Western stars enriches the Dracula conceit of The Only Good Indian. To correct the Indian-hating of the genre and to exhume the deadly history of US colonialism, one must drive a stake through the heart of the Western's murderous code hero and release the Indian from Hollywood's thrall.

The final showdown between Black Fox and McCoy confirms redemption for the Cherokee warrior and a welcome release for the tortured sheriff. Moreover, it represents a deliberate over-the-top iteration of the Western's showdown scene. Before the two men fire on each other, McCoy proclaims, "You ain't no goddam Sam Franklin. You are Black Fox. Heathen. That's all you'll ever be." "That's the only thing you've ever been right about in your whole damn life," Black Fox declares and then draws his gun. Both men shoot; both fall; only McCoy rises. Before McCoy can finish off his foe, Nachwihiata reappears and jumps him, only to be subdued and ordered to set Black Fox on fire. McCoy eulogizes, "When I knew Black Fox, he was a good Injun. A warrior. A damn good Injun." At this point, Black Fox rises as if from the dead (a brass plate in his shirt pocket has stopped the bullet) to kill McCoy. The sheriff soon lies blood-soaked on the ground, his side pierced and his arms outstretched like a crucifixion. The resemblance to Christ is intentional, signaling not McCoy's sacrificial death (he is Dracula, after all) but the role of Christianity in justifying the violence of warfare and systematic acculturation alike. ${ }^{72}$ Death obliterates the captor, as the voiceover narration from Dracula indicates: "It was like a 
miracle; but before our very eyes, and almost in the drawing of a breath, the whole body crumbled into dust and passed from our sight." ${ }^{\text {"73 }}$ The body of McCoy fades from the screen and is replaced with an image of the Dracula text superimposed on the outline of the church against a red sky. Nachwihiata's reading rings with the memories of the boarding school: "It was almost impossible to believe that the things which we had seen with our own eyes and heard with our own ears were living truths. Every trace of all that had been was blotted out. The castle stood as before, reared high above a waste of desolation." ${ }^{\text {74 }}$ Black Fox and Nachwihiata depart from the desolation for home and reunion.

The Only Good Indian underscores its inversion of The Searchers (by way of the horror film) through opening and closing shots that quote the film - with a difference. As The Searchers famously opens with Martha Edwards emerging from the family's dark doorway to the image of Edwards approaching on horseback, The Only Good Indian opens with Nachwihiata's mother exiting the family cabin to the open Kansas prairie. The Searchers ironically concludes with a parallel shot of the Jorgensen family home as they watch the arrival of Edwards, Pawley, and Debbie. With the camera looking outward from the interior of the darkened house, the Jorgensens escort Debbie into her new home; their daughter escorts in Pawley, her fiancé; and Edwards turns and walks off alone, framed by the closing door - an image meant to capture "the closing of the frontier" and exclusion of both the Indian and his now-antiquated white nemesis. ${ }^{75}$ The Only Good Indian could have a parallel ending, with Black Fox turning to leave after watching Nachwihiata's parents gently escort the wounded boy back into his home. Indeed, Black Fox first turns to ride back into the prairie, discarding the Sam Franklin Detective Agency brass nameplate that inadvertently saved his life; however, the wounded Nachwihiata comes back out to welcome him into their home. The door and the film close not on the lone code-hero retreating from the domestic, familial space that indicates the so-called winning of the West; instead, it concludes with his incorporation as a second father or grandfather in a secure Native home [Figure 5]. The song that plays over the film's final credits is "Come to Me Great Spirit," a traditional healing song performed by Defoe, the actor who plays Sally. ${ }^{76}$ At the close of this traumatic tale, explained Carmody, "All the characters need to heal" from literal and emotional wounds, and the closing scene promises that process will begin in Nachwihiata's home. ${ }^{77}$ In the era of the Dawes Severalty Act of 1887 and Indian boarding schools, this composite Native family's sovereign domestic mutuality stands as an emblem of survivance.

\section{The White Man}

Willmott admits to being "a history guy," determined in his films to explore the past, because the past "is all about today. ... There's no such thing as the past; things change a little bit and things change back." ${ }^{78}$ This outlook can readily be seen in the most well-known film he has directed, C.S.A.: The Confeder- 


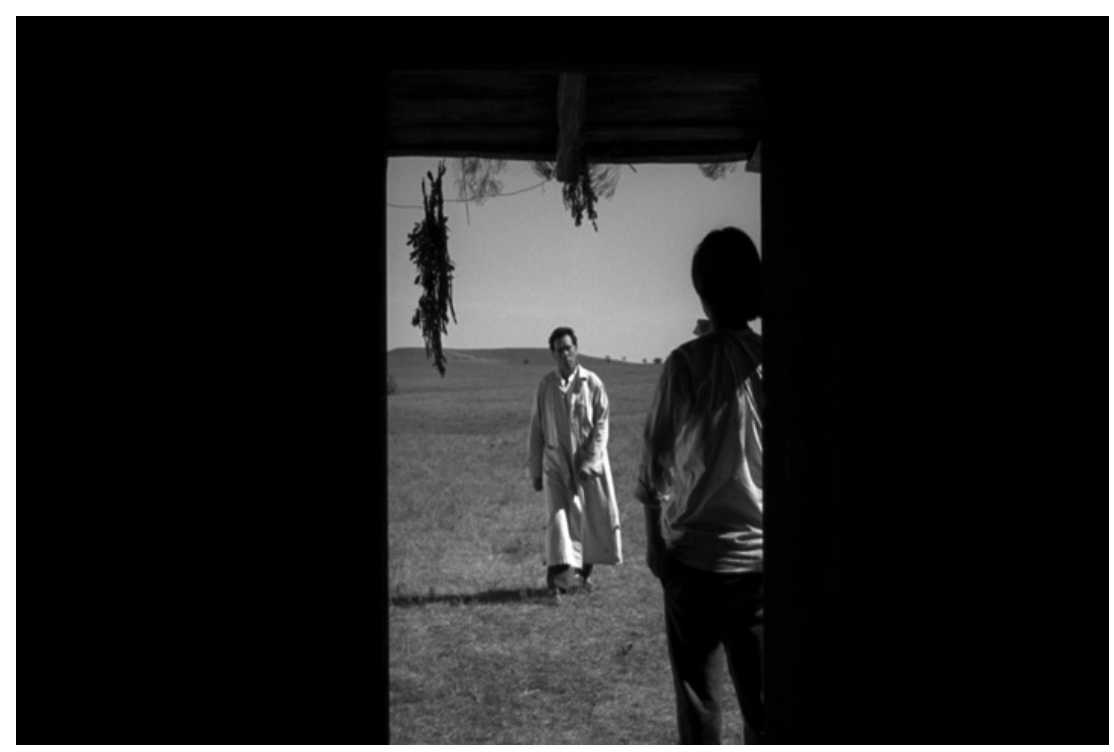

Figure 5: Black Fox enters Nachwihiata's home in a shot that reverses the conclusion of The Searchers.

ate States of America (2004), an alternate history depicting the ramifications of a Southern Civil War victory in the form of a television mockumentary. To represent a Confederate nation, Willmott pairs newly shot scenes with archival footage from the history of the United States, including images of lynchings, segregation, and civil rights protests. In addition, to compose the commercials that punctuate the feature documentary_ads for such things as slave shackles and a chicken restaurant-Willmott draws upon the wealth of racist caricatures in the history of American advertising. The resulting narrative of a nation's institutionalized racism and the physical and economic exploitation of African Americans is, then, dishearteningly familiar. In C.S.A., Willmott uses the genres of the documentary and television advertisement to make visible the persistent legacies of slavery.

At one point in C.S.A., a Native academic portrayed by Haskell professor Dan Wildcat shares the wisdom of an elder: "no one can play the white man like a white man." This conclusion jangles with Franklin's insistence in The Only Good Indian that he can "out white man the goddam white man," but it also points to another central concern in Willmott's work: the historically persistent lure of Euro-American hegemony. Reflecting on Franklin's troubling words, Willmott emphasizes, 'For me, when you say 'the white man,' you're not talking about white people, you're talking about something even bigger than race, you're talking about something that race has created to some degree but it is a philosophy, it is an entitlement." "Th "That's what Franklin is really seeing," continues Willmott, so Franklin tells himself, "I want to be one of those 
guys" - one of those who, cloaked in the gospel of white superiority, write the law and wield force to achieve economic, cultural, and physical dominance over the majority of fellow humans. It is a position hard not to covet. The Only Good Indian fleshes out this impulse early on when the fugitive Nachwihiata enters the dying town of Harkin, a Kansas freedmen's town hit hard by the relocation of the train line that once sustained it.$^{80}$ The remaining residents, who presumably have their own narratives of brutal captivity to recount, vote to restrain Nachwihiata and return him to Haskell for much-needed cash. The town's patriarch and namesake (played by Paul Butler) disagrees with the decision, and he and his wife intend to help the boy escape that evening when Franklin shows up and foils their plan. Like Franklin, the Harkin residents who vote to retain Nachwihiata are well versed in the white man's commodification of bodies and view such actions as essential to their survival. Freedom appears dependent on another's captivity.

Yet Franklin's reference to the white man, viewed in the larger context of the film's place within the genre of the revisionist Western, comes to have a resistant register as well. As David Lusted details, the potential for and barriers to black-Native alliance on the American frontiers of the past and the present have been explored in several revisionist Westerns since the mid-twentieth century, including a handful that fall under the categories of blaxploitation and "gangsta" Westerns. Sidney Poitier's Buck and the Preacher (1971), for example, references the participation of African American soldiers in the Indian wars but "ends with one of the wittiest inversions of a cavalry rescue in a Western," as a wagon train of formerly enslaved African Americans is rescued from white bounty hunters by American Indians. ${ }^{81}$ Mario Van Peeble's hyperviolent Posse (1993) makes a point of pairing the sins of Native dispossession and African slavery as it reclaims a lost history of black cowboys. Willmott has indicated that the films he watched as a child, including the work of Gordon Parks, continue to influence him and that Franklin's expression that he wishes to "out white man the goddam white man" is inspired by the protagonists of blaxploitation films - figures marked by defiance of white hegemony. ${ }^{82}$ Franklin's eventual embrace of his Cherokee name, Black Fox, further suggests a link between his newfound opposition to the "entitlement" of whites and the defiance of the blaxploitation hero. The Only Good Indian concludes by casting aside the white-man model; when Black Fox finds his place not in the Pinkerton Agency but in a Kickapoo home, he achieves freedom by securing rather than wresting others' freedom.

Nonetheless, just as the meaning of "out white man the goddam white man" registers the potential for Franklin to reclaim the name of Black Fox, so the concluding victory of Nachwihiata and Black Fox depends on their shared ability — gained through the experience and narratives of captivity - to best the captor at his own violent game. After Franklin reclaims his identity as Black Fox, his experience of ideological captivity is essential to victory over McCoy, as represented in the materials of their final showdown. The brass plate that 
stops a bullet near Black Fox's heart is inscribed with his "white man" name and profession, and a wooden cross connects with the embedded Indian blade to rid the world of McCoy. Reconsidered at the close of the film, Franklin's troubling declaration has become a radical philosophy of resistance. The boarding school, anti-Western, gothic-horror, and even blaxploitation genres are apt bedfellows for a film more concerned with resilience than victimhood.

Kathryn Derounian-Stodola and James Levernier conclude their study of the Indian captivity narrative as follows: "As long as the American frontier exists as a real or imagined entity, permutations of the captivity narrative and the captivity psychology will no doubt continue to evolve." 83 The Only Good Indian explicitly ties the evolution of the captivity narrative-its travel across genres and between cultures - to the joined acts of reclaiming repressed histories and appropriating dominant narratives. It is fitting, then, that the film has been the occasion for audience narration of boarding school experiences. According to Carmody, during the months when the film was broadcast on cable, he received e-mails from many viewers with relatives who attended Indian boarding schools or had themselves been enrolled. Willmott recalls in particular the reception of the film at an Anchorage, Alaska, screening, where audience members approached him to share stories of their boarding school experiences and those of their parents and grandparents. ${ }^{84}$ Such responses confirm that the boarding school legacy, unlike the remains of Dracula, will never simply vanish; a stake through the heart does not disappear a stereotype or the warfare and institutionalization inextricably linked to it. But works that challenge the dominant portrait of white captivity in America prompt more narratives, revisions, and unshacklings of the past. The intertextuality of The Only Good Indian prompts viewers to set aside a simple account of the progression from captivity narrative, to dime novel, to Western and instead turn their attention to a rich matrix of texts that have long symbolically and materially challenged the "white man" narratives of Euro-American imperialism.

\section{Notes}

The author thanks Kevin Willmott and Thomas Carmody for their generosity, Stephanie Fitzgerald and anonymous reviewers for American Studies for comments on earlier drafts, Phil Hauptman for help with the images, and finally, her students at the University of Kansas, who first helped her see The Only Good Indian's deep intertextuality.

1. Neal Salisbury, "Introduction: Mary Rowlandson and Her Removes," in The Sovereignty and Goodness of God and Related Documents, by Mary Rowlandson (Boston: Bedford Books, 1997), 55.

2. Kathryn Zabelle Derounian-Stodola, "Introduction," in Women's Indian Captivity Narratives (New York: Penguin Books, 1998), xi. As Pauline Turner Strong writes, "Over the course of three centuries, the capture of a defenseless settler by Indians has been featured in Anglo-American folklore and popular media... becoming in the twentieth century a conceptual model for representing American relations with currently more threatening Others." Pauline Turner Strong, American Indians and the American Imaginary: Cultural Representation across the Centuries (Boulder: Paradigm Publishers, 2012), 72.

3. Richard Slotkin, Gunfighter Nation: The Myth of the Frontier in Twentieth-Century America (New York: Atheneum, 1992), 15. The other two titles in Slotkin's trilogy are Regeneration through Violence: The Mythology of the American Frontier, 1600-1860, rpt. (New York: HarperPe- 
rennial, 1996), and The Fatal Environment: The Myth of the Frontier in the Age of Industrialization, 1800-1890, rpt. (New York: HarperPerennial, 1994). For a discussion of the genre's evolution from the late sixteenth through the nineteenth centuries and its transference into the genres of history, folklore, children's literature, and the novel, see especially Kathryn Zabelle Derounian-Stodola and James Levernier, The Indian Captivity Narrative, 1550-1900 (New York: Twayne, 1993), chap. 1 and 6. On the textual and performative roots of Native American stereotypes in twentieth-century films, see Jacquelyn Kilpatrick, Celluloid Indians: Native Americans and Film (Lincoln: University of Nebraska Press, 1999), chap. 1.

4. June Namias, White Captives: Gender and Ethnicity on the American Frontier (Chapel Hill: University of North Carolina Press, 1993), 11.

5. Joshua David Bellin, The Demon of the Continent: Indians and the Shaping of American Literature (Philadelphia: University of Pennsylvania Press, 2001), 6. Bellin examines in particular the captivity narratives of Mary Rowlandson, Mary Jemison, John Dunn Hunter, and John Tanner, and emphasizes that "any American text... has been forged by the processes of encounter within which it exists."

6. Shari M. Huhndorf, Going Native: Indians in the American Cultural Imagination (Ithaca, NY: Cornell University Press, 2001), 189n39; Jeanette Hoorn, "Captivity and Melancholia in Marlon Fuentes' Bontoc Eulogu: Revisiting Meet Me in St. Louis," in Body Trade: Captivity, Cannibalism and Colonialism in the Pacific, ed. Barbara Creed and Jeanette Hoorn (New York: Routledge, 2001), 279n4. Salisbury emphasizes that American Indians captive among whites "far outnumber those of whites among Indians" ("Introduction," 55).

7. K. Tsianina Lomawaima, "American Indian Education: By Indians versus for Indians," in A Companion to American Indian History, ed. Philip Joseph Deloria and Neal Salisbury (Malden, MA: Blackwell, 2002), 423. On Eastman, Standing Bear, and Zitkala-Ša's strategic use of their boarding school education as seen in their autobiographical writings, see especially Lucy Maddox, Citizen Indians: Native American Intellectuals, Race, and Reform (Ithaca, NY: Cornell University Press, 2005), chap. 4. Since the 1990s, a number of studies have appeared that document boarding school students' experiences and strategies of resistance, including K. Tsianina Lomawaima, They Called It Prairie Light: The Story of Chilocco Indian School (Lincoln: University of Nebraska Press, 1994); David Wallace Adams, Education for Extinction: American Indians and the Boarding-School Experience, 1875-1928 (Lawrence: University Press of Kansas, 1995); Brenda J. Child, Boarding School Seasons American Indian Families, 1900-1940 (Lincoln: University of Nebraska Press, 1998); and Myriam Vučković, Voices from Haskell: Indian Students between Two Worlds, 1884-1928 (Lawrence: University Press of Kansas, 2008).

8. On the evolution of the Western, including its response to war, social unrest, and new narratives of the frontier and its incorporation of elements from other film genres, see especially David Lusted, The Western (Harlow, Essex: Pearson/Longman, 2003), and Mary Lea Bandy, Ride, Boldly Ride: The Evolution of the American Western (Berkeley: University of California Press, 2012).

9. The Only Good Indian, directed by Kevin Willmott (TLC Productions, 2009), DVD. At the American Indian Film Festivalsupporting actor. The film also had enthusiastic audiences at the Newport Beach International Film Festival, Michael Moore's Traverse City Film Festival, and the Tallgrass Film Festival in Wichita, and it aired on the cable channel Starz. Despite such recognitions, The Only Good Indian has never found a domestic distributor. See "Only Good Indian" Sweeps Awards," Topeka Capital-Journal, November 18, 2009, accessed July 30, 2013, http:// cjonline.com/news/state/2009-11-18/only_good_indian_sweeps_awards, and Jon Niccum, "Western Union: 'Only Good Indian' Explores Cultural History through Revisionist Drama," Lawrence Journal World, November 6, 2009, accessed May 3, 2013, http://www2.ljworld.com/news/2009/ nov/06/western-union-only-good-indian-explores-cultural-h/.

10. When the buildings were completed in July 1884, the school was officially named the US Indian Industrial Training School, but it soon came to be called Haskell Institute in honor of recently deceased Congressman Dudley Chase Haskell, who represented the Kansas Second Congressional District and chaired the House Committee on Indian Affairs. The school officially opened in September 1884. The institution is now called Haskell Indian Nations University, a Bureau of Indian Education-supported tribal university that awards associate and baccalaureate degrees. See Theresa Milk, Haskell Institute: 19th Century Stories of Sacrifice and Survival, with a Haskell Cemetery Walking Tour (Lawrence, KS: Mammoth Publications, 2007), 7, and Vučković, Voices from Haskell, 19.

11. Caroline Stanley, "Sundance Filmmaker Interview: Kevin Willmott on The Only Good Indian," Flavorwire, January 26, 2009, accessed August 20, 2013, http://flavorwire.com/8924/ sundance-filmmaker-interview-kevin-willmott-on-the-only-good-indian.

12. Willmott's filmography includes C.S.A.: The Confederate States of America (2004), a television mockumentary, complete with advertisements, recounting the ramifications of a Southern Civil War victory; Destination: Planet Negro (2013), a spoof of mid-century sci-fi flicks in which African Americans attempting to escape Earth for Mars in 1939 land in the twenty-first-century United States; Jayhawkers (2014), a sport film concerning Wilt Chamberlain's experience integrating the University of Kansas basketball team in the 1950s; and Gordon Parks Elementary (2015), 


\section{Laura L. Mielke}

a documentary about a Kansas City, Missouri, charter school. Perhaps most prominently, Willmott cowrote with director Spike Lee Chi-Raq (2015), a modern-day adaptation of Lysistrata focused on gun violence in Chicago.

13. Julia Good Fox, "Reel Bad Indians: A Cinematic Reflection on Kevin Willmott's 'The Only Good Indian," Good Fox: Culture. Politics. Indian Country, November 2009, accessed May 3, 2013, http://juliagoodfox.com/2009/11/14/reel_bad_indians/.

14. Vučković, Voices from Haskell, 20; Adāms, Education for Extinction, 56-57.

15. Vučković, Voices from Haskell, 13.

16. Lomawaima, "American Indian Education," 426.

17. Vučković, Voices from Haskell, 73.

18. These words are generally credited to General Philip Sheridan in 1869, but Congressman James Michael Cavanaugh of Montana appears to have offered the sentiment one year earlier. See Wolfgang Mieder, “'The Only Good Indian Is a Dead Indian': History and Meaning of a Proverbial Stereotype," Journal of American Folklore 106 (1993): 42. doi:10.2307/541345.

19. The notion of the "bad Indian" plays a powerful role in Deborah Miranda's (Ohlone Costanoan Esselen) Bad Indians: A Tribal Memoir (Berkeley, CA: Heyday, 2013), a work of indigenous history and memoir that challenges received narratives of the California Indians, namely, their conversion and disappearance. As Miranda affirms, when the dominant claim is "An only good Indian is a dead Indian," the term "bad Indian" is an affirmation of Native life.

20. Geiogahma and Wildcat are listed as a coexecutive producers, along with J.T. O’Neal. The film credits thank Kickapoo tribe members Steve Cadue, Whitewater, and Howard Allen; Prairie Band Potawatomie Nation representative Warren "Junior" Wahweotten; and Dr. Linda Sue Warner, then president of Haskell Indian Nations University.

21. Author interview with Thomas L. Carmody, July 24, 2013.

22. Gerald Robert Vizenor, Manifest Manners: Postindian Warriors of Survivance (Hanover: University Press of New England for Wesleyan University Press, 1994), 5. Standing Bear was also a performer in Wild West shows and early film. See Philip Joseph Deloria, Indians in Unexpected Places (Lawrence: University Press of Kansas, 2004), 75-78.

23. In my characterization of American Indians' appropriation of so-called non-Native genres and technologies in the late nineteenth and early twentieth centuries, including autobiography, opera, film, sports, automobiles, and visual art, I draw in particular on two essential works on the period: Deloria, Indians in Unexpected Places, and Maddox, Citizen Indians.

24. Milk, Haskell Institute.

25. Quoted in ibid., 76.

26. Vučković, Voices from Haskell, 227-28.

27. Ibid., 73.

28. Quoted in ibid., 90.

29. Ibid., 4.

30. David A. Baerreis, "Foreword," in The Middle Five: Indian Schoolboys of the Omaha Tribe, by Francis La Flesche (Lincoln: University of Nebraska Press, 1978), ix-xiii.

31. Cathy Davidson and Ada Norris, "Introduction," in American Indian Stories, by ZitkalaŠa (New York: Penguin Books, 2003), 15-16.

32. Zitkala-Sa, American Indian Stories, ed. Cathy Davidson and Ada Norris (New York: Penguin Books, 2003), 91.

33. Ibid., 96.

34. Ibid., $93,97$.

35. The portrait of a child's experience at boarding school is limited to the first five sections of "School Days," at the end of which Zitkala-Ša declares, "The melancholy of those black days has left so long a shadow that it darkens the path of years that have since gone by." Ibid., 97. Her melancholic recounting likewise dominates much scholarly discussion of her work.

36. Good Fox, "Reel Bad Indians." Willmott describes the boarding school as the "inciting incident" or "controlling idea of the film"- the place from which this revisionist Western starts. Author interview with Kevin Willmott, July 29, 2013. The Searchers, discussed later, also begins with an intense sixteen minutes of inciting events (the introduction of the Edwards family followed by the Comanche attack on their home) that loom over the rest of the film.

37. Francis La Flesche, The Middle Five: Indian Schoolboys of the Omaha Tribe (Lincoln: University of Nebraska Press, 1978), 87.

38. Ibid., 138.

39. Ernest Stromberg, "Resistance and Mediation: The Rhetoric of Irony in Indian Boarding School Narratives by Francis La Flesche and Zitkala-Ša," in American Indian Rhetorics of Survivance: Word Medicine, Word Magic, ed. Ernest Stromberg (Pittsburgh: University of Pittsburgh Press, 2006), 101

40. Zitkala-Ša, American Indian Stores, 113. In his study of La Flesche and Zitkala-Ša's uses of irony, Stromberg concludes, "It is the knowledge and mastery of the discourse of the dominant culture...that enables both writers to employ irony in ways that are by turns razor sharp and sledgehammer blunt in their critiques." Ibid., 108. 


\section{Transforming Captivity Narratives 29}

41. Lomawaima, "American Indian Education," 423.

42. Slotkin, Gunfighter Nation, 635.

43. Imprint, directed by Michael Linn (MTI Home Video, 2007), DVD, and Older than America, directed by Georgina Lightning (IFC Films, 2008), DVD. Imprint won best film, best director, best actor (Michael Spears), best actress (Tonantzin Carmelo), and best supporting actress (Carla-Rae Holland) at the 2007 American Indian Film Festival. Older than America won best director and best supporting actor (Studi) at the 2008 American Indian Film Festival.

44. On critiques of Dances with Wolves, including the romance of playing Indian and the portrait of the Lakota people as doomed, see especially Kilpatrick, Celluloid Indians, 127-30. In chapter six, Kilpatrick discusses the emergence of an "American Indian aesthetic" in films written, directed, produced, and acted by Native Americans.

45. Teresa A. Goddu, Gothic America: Narrative, History, and Nation (New York: Columbia University Press, 1997), 5.

46. The presence of these books in the film has historical basis; the Haskell superintendent ordered hundreds of books for the school library in 1901, including "adventure stories for boys" and girls' books reflecting "the values and expectations associated with the Victorian ideal of true womanhood." Vučković, Voices from Haskell, 103. On the relevance of the broader gothic genre to Nachwihiata's situation, Willmott comments, "the narrative really could have gone either way..., Frankenstein or Dracula." Author interview with Willmott.

47. Bram Stoker, Dracula (Oxford: Oxford University Press, 1983), 10.

48. Ibid., $15,36$.

49. Salisbury, "Introduction," 55; Derounian-Stodola and Levernier, Indian Captivity Narrative, 94

50. Mary White Rowlandson, The Sovereignty and Goodness of God and Related Documents, ed. Neal Salisbury (Boston: Bedford Books, 1997), 90.

51. Sacvan Bercovitch, The Puritan Origins of the American Self (New Haven, CT: Yale University Press, 1975), 37.

52. Rowlandson, Sovereignty and Goodness, 103.

53. Bercovitch, Puritan Origins, 117. Strong writes that from the 1670 s through the early 1700 s, New England clergy "interpreted the intercolonial wars primarily as spiritual battles against the heathenism of Rome and America alike, expanding the captivity metaphor to encompass a redemptive experience not only for captives but for the community as a whole." However, Strong argues, Rowlandson's work departs somewhat from the clerical writing, falling less into the category of the jeremiad than into that of spiritual autobiography. Strong, American Indians, 90.

54. Goddu, Gothic America, 10.

55. Good Fox, "Reel Bad Indians."

56. Strong, American Indians, 86.

57. Author interview with Carmody.

58. Francis Paul Prucha, The Great Father: The United States Government and the American Indians, abridged (Lincoln: University of Nebraska Press, 1986), 150.

59. Author interview with Willmott.

60. Vizenor, Manifest Manners, 7. Jane Tompkins observes that Indians in Westerns "functioned as props, bits of local color, textual effects. As people they had no existence." Jane P. Tompkins, West of Everything: The Inner Life of Westerns (New York: Oxford University Press, 1992), 8.

61. Lusted, The Western, 233.

62. Quoted in Niccum, "Western Union." On revisionist Westerns that challenge the traditional portrait of the savage or doomed Indian, see especially Lusted, The Western, 238-46.

63. Willmott notes how unusual it is for a prominent Native actor like Studi to play "a modern person" and that the character of Franklin was important for that reason, as well as for his representation of the pressures of acculturation. Author interview with Willmott.

64. Good Fox notes the reference here to a speech by Maxwell Scott in the film The Man Who Shot Liberty Valance. Good Fox, "Reel Bad Indians." McCoy's emotional response to the film recalls the story that early audiences of the first Western, The Great Train Robbery (1903), were shocked when a robber fires his gun into the camera/audience.

65. Glenn Frankel, The Searchers: The Making of an American Legend (New York: Bloomsbury, 2013), 4.

66. Kilpatrick, Celluloid Indians, 61.

67. Armando José Prats, Invisible Natives: Myth and Identity in the American Western (Ithaca, NY: Cornell University Press, 2002), 281.

68. "Kevin Willmott, 'The Only Good Indian': Westerns, Representation and Revisionism [Interview]," Indiewire, January 17, 2009, accessed August 20, 2013, http://www.indiewire.com/ article/kevin_willmott_the_only_good_indian_westerns_representation_and_american_hi; author interview with Carmo $\bar{d} y$.

69. Thomas Fox Averill, "Review of The Only Good Indian," Kansas History: A Journal of the Central Plains 34 (Summer 2011): 162. 


\section{Laura L. Mielke}

70. Both of these characters share these qualities of the Western protagonist: "self-discipline; unswerving purpose; the exercise of knowledge, skill, ingenuity, and excellent judgment; and a capacity to continue in the face of total exhaustion and overwhelming odds." Tompkins, West of Everything, 12.

71. Author interview with Willmott.

72. Ibid.

73. Stoker, Dracula, 377.

74. Ibid., 378.

75. Prats, Invisible Natives, 285.

76. Defoe's recording appeared on the 2009 compilation Come to Me Great Mystery (Silver Wave Records), which won the 2009 Grammy for best Native American music album.

77. Author interview with Carmody.

78. Author interview with Willmott.

79. Ibid.

80. Harkin is modeled after such Kansas towns as Nicodemus and Dunlap, which were established by and for African Americans in the postbellum era and faced population decline as the century came to a close.

81. Lusted, The Western, 249. This is a strain lost, however, in Quentin Tarantino's Django Unchained (2012), whose African American protagonist pursues bloody vengeance against the white slaveholder in a landscape seemingly vacated by Native Americans.

82. Stanley, "Sundance Filmmaker Interview"; Ryan Wright, "In the Making of 'Chiraq,' KU Professor Kevin Willmott Explores Race Relations," University Daily Kansan, September 9, 2015, accessed January 26, 2016, http:/www.kansan.com/arts_and_culture/in-the-making-of-chiraq-kuprofessor-kevin-willmott-explores/article 5304ef94-55a $\overline{6}-11 \overline{\mathrm{e}} 5-\mathrm{a} 3 \mathrm{ca}-4 \mathrm{~b} 1729 \mathrm{fl}$ bce.html.

83. Derounian-Stodola and Levernier, Indian Captivity Narrative, 191.

84. Author interview with Carmody; Niccum, "Western Union." 